\title{
New antibiotics in the treatment of urinary tract infections
}

\author{
F.M. Wagenlehner, orcid: 0000-0002-2909-0797, \\ e-mail: florian.wagenlehner@chiru.med.uni-giessen.de
}

\section{Justus-Liebig-University Giessen, Giessen, Germany}

\section{Keywords:}

urinary tract infections, europe, resistance, antibiotics

\section{For citation:}

ДСТУ 8302 2015:

Wagenlehner F.M. New antibiotics in the treatment of urinary tract infections. Урологія. 2021. Т. 25, № 2. C. 97-101. DOI: $10.26641 / 2307-$ 5279.25.2.2021.238219.

APA:

Wagenlehner, F.M. (2021). New antibiotics in the treatment of urinary tract infections. Urologiya, 25(2), 97101. DOI: $10.26641 / 2307-5279.25$. 2.2021.238219.

\section{SUMMARY}

Antibiotics are very often prescribed for the indication urinary tract infections (UTIs). Therefore, UTIs are an important field for the development of antibiotic resistance. A number of new antibiotics have been tested for the indication complicated UTI / pyelonephritis. These are cephalosporins and carbapenems, in combination with new beta-lactamase inhibitors, cefiderocol as a new type of cephalosporin, plazomicin a new aminoglycoside, eravacycline a new tetracycline, and intravenous fosfomycin. Not all antibiotics are approved in Europe. Although the development of these new substances is promising, these new antibiotics should be used very carefully to avoid the development of new antibiotic resistance against these new substances.
Urinary tract infections (UTIs) are among the most common bacterial infections in outpatient practice and in hospitals and occur in many specialist areas, such as internal medicine, gynecology, urology, intensive care medicine, etc. The clinical spectrum of urinary tract infections ranges from benign to life-threatening infections (1). Antibiotics are very often prescribed for the indication UTI, therefore UTIs are an important field for the development of antibiotic resistance. Most of the new antimicrobials that are effective against gramnegative bacteria have been studied in complicated UTI / pyelonephritis. The clinical studies of phases 2 and 3 that have been carried out in the last 5 years for this indication are presented here.

In the ASPECT cUTI phase 3 study from 2015, ceftolozane / tazobactam $1.5 \mathrm{~g} / \mathrm{q} 8 \mathrm{~h}$ was compared with a high levofloxacin dose of $750 \mathrm{mg} / \mathrm{q} 24 \mathrm{~h}$ in
1083 patients with complicated UTI / pyelonephritis (2). The duration of treatment was 7 days. Patients were included if they had symptoms, pyuria, and significant bacteriuria, defined as e $\geq 10^{5} \mathrm{CFU} / \mathrm{ml}$. The co-primary endpoint was microbiological eradication and clinical cure 5-9 days after treatment. The composite cure rates were $76.9 \%$ in the ceftolozane / tazobactam arm and $68.4 \%$ in the levofloxacin arm, confirming the superiority of ceftolozane / tazobactam.

In the phase 3 RECAPTURE study, ceftazidime / avibactam $2.5 \mathrm{~g} / \mathrm{q} 8 \mathrm{~h}$ was compared with doripenem $500 \mathrm{mg} / \mathrm{q} 8 \mathrm{~h}$ in 1033 patients with complicated UTI / pyelonephritis (3). The duration of treatment was 10 to 14 days, with the option of oral down step therapy with ciprofloxacin or trimethoprim / sulfamethoxazole after 5 days i.v. therapy. The co-primary endpoints were the 
proportion of patients with symptomatic cure of UTI-specific symptoms (clinical cure) on day 5 and the proportion of patients with both microbiological eradication and symptomatic cure of UTI-specific symptoms on the Test of Cure (TOC). The clinical cure rate was $70.2 \%$ for ceftazidime / avibactam and $66.2 \%$ for doripenem on day 5 , confirming non-inferiority. The combined symptomatic cure / microbiological eradication at TOC was $71.2 \%$ for ceftazidime / avibactam and $64.5 \%$ for doripenem and showed superiority.

In a pilot study from 2017, therapy in 36 patients with pyelonephritis by ESBL-producing E. coli was investigated (4). All patients received an i.v. carbapenem for 3 days and were then randomized to either oral sitafloxacin $100 \mathrm{mg} / \mathrm{q} 12 \mathrm{~h}$ or i.v. Ertapenem $1 \mathrm{~g} / \mathrm{q} 24 \mathrm{~h}$. The primary endpoint was clinical cure on day 10 . The clinical cure rates were $100 \%$ in the sitafloxacin group and $94.1 \%$ in the ertapenem group, which showed statistically comparable results in both groups. $94.4 \%$ of the ESBL E. coli isolates were sensitive to sitafloxacin.

A randomized, open study from 2017 examined piperacillin / tazobactam $4.5 \mathrm{~g} / \mathrm{q} 6 \mathrm{~h}$ versus cefepime $2 \mathrm{~g} / \mathrm{q} 12 \mathrm{~h}$ or ertapenem $1 \mathrm{~g} / \mathrm{q} 24 \mathrm{~h}$ in 72 patients with nosocomial UTIs due to ESBLproducing E. coli, including septic shock (5). The duration of treatment was 10 to 14 days. The clinical cure rates were $93.9 \%$ with piperacillin / tazobactam and $97 \%$ with ertapenem, and the difference was not statistically significant. After 6 patients had been recruited into the cefepime group, the assignment to cefepime was terminated prematurely due to the high failure rate in $4 / 6$ patients, including 2 deaths.

A phase 2 study from 2017 compared imipenem / relebactam $625 \mathrm{mg} / \mathrm{q} 6 \mathrm{~h}$ with imipenem / relebactam $750 \mathrm{mg} / \mathrm{q} 6 \mathrm{~h}$ or imipenem alone 500 mg / q6h in 302 patients with complicated UTI / pyelonephritis (6). The duration of treatment was up to 14 days, and oral therapy with ciprofloxacin was possible after 4 days i.v. treatment. The primary endpoint was the proportion of patients with a microbiological response. The microbiological response rates were $95.5 \%$ for imipenem / relebactam $750 \mathrm{mg}, 98.6 \%$ for imipenem/ relebactam $625 \mathrm{mg}$, and $98.7 \%$ for imi penem alone, and demonstrated non-inferiority for both regimens.

The 2018 TANGO I phase 3 study compared meropenem / vaborbactam 4g / q8h with piperacillin / tazobactam $4.5 / \mathrm{q} 8 \mathrm{~h}$ in 585 patients with complicated UTI / pyelonephritis (7). The duration of treatment was 10 days. Oral therapy with levofloxacin $500 \mathrm{mg} / \mathrm{q} 24 \mathrm{~h}$ was possible after 5 days i.v. treatment. The primary endpoint was clinical cure and microbiological eradication at the end of the i.v. treatment. The overall success rate was $98.4 \%$ with meropenem / vaborbactam versus $94.0 \%$ with piperacillin / tazobactam, meeting at least non-inferiority of meropenem / vaborbactam.

In a phase 2 study from 2018, cefiderocol $2 \mathrm{~g} /$ q8h was compared with imipenem / cilastatin $1 \mathrm{~g} /$ q8h in 495 patients with complicated UTI / pyelonephritis $(8,9)$. The duration of treatment was 7 to 14 days. The primary efficacy endpoint was clinical and microbiological response. Patients were included if they had symptoms, pyuria, and bacteriuria with gram-negative uropathogens e" $10^{5} \mathrm{CFU} / \mathrm{ml}$ who were sensitive to the study drugs. The combined clinical and microbiological response was $73 \%$ in the cefiderocol group and 55\% in the imipenem / cilastatin group. Statistically, this achieved noninferiority. Microbiological cure was superior for cefiderocol.

In the IGNITE3 phase 3 study from 2018, eravacycline $1.5 \mathrm{mg} /$ body weight / q24h was compared with ertapenem $1 \mathrm{~g} / \mathrm{q} 24 \mathrm{~h}$ in 1205 patients with complicated UTIs (10). The duration of treatment was 5 to 10 days. The co-primary endpoints were a combination of clinical cure and microbiological success. The combined clinical and microbiological response rates were $68.5 \%$ for eravacycline and $74.9 \%$ for ertapenem. Statistically, non-inferiority was not achieved.

The ZEUS study was a phase $2 / 3$ study from 2019 in which fosfomycin i.v. 6 g / q8h versus pi peracillin / tazobactam $4.5 \mathrm{~g} / \mathrm{q} 8 \mathrm{~h}$ in 465 patients with complicated UTI / pyelonephritis was compared (11). The duration of treatment was 7 to 14 days. The primary efficacy endpoint was clinical and microbiological response. The combined clinical and microbiological response was $64.7 \%$ in the fosfomycin group and $54.5 \%$ in the piperacillin / tazobactam group, showing statistically noninferiority. A post-hoc analysis was carried out to redefine the microbiological eradication through molecular genotyping and led to a virtually superior result in favor of fosfomycin.

The EPIC phase 3 study from 2019 examined plazomicin $15 \mathrm{mg} /$ body weight q24h versus meropenem $1 \mathrm{~g} / \mathrm{q} 8 \mathrm{~h}$ in 609 patients with complicated UTI / pyelonephritis (12). The duration of treatment was 7 to 10 days, with an optional oral therapy after 4 days i.v. therapy. The primary endpoint was clinical and microbiological response. It was required that at least one qualifying pathogen that was sensitive to both meropenem and plazomicin was present. On day 5, the response was $88.0 \%$ in the plazomicin arm and $91.4 \%$ in the meropenem arm, confirming non-inferiority. At TOC, the response was $81.7 \%$ in the plazomicin arm and $70.1 \%$ in the meropenem arm, which showed statistical superiority. 
A number of new antibiotics or fixed antibiotic combinations have been tested in the last 5 years for the indication of complicated UTI / pyelonephritis. On the one hand there are cephalosporins and carbapenems, which have been combined with new beta-lactamase inhibitors. These studies have shown that this creates new therapeutic options for ESBL-producing enterobacteria and, in some cases, carbapenemase-producing bacteria. A new cephalosporin, cefiderocol, mediates a new mechanism in which the antibiotic molecule complexes with iron ions and is absorbed into the bacterial cell as a complex via special iron absorption systems, thus avoiding a resistance mechanism. The broad antibacterial spectrum of cefiderocol is very promising. A new tetracycline (eravacycline) has not been approved for UTIs because it was less effective than ertapenem. A new aminoglycoside plazomicin showed very good results even with multi-resistant pathogens. The company was unable to develop the drug further due to economic factors, so it is not approved in Europe. As an already approved antibiotic, fosfomycin administered as i.v. therapy could show that it is suitable as a monotherapeutic agent for the indication of complicated UTI / pyelonephritis.

Even though the development of these new antibiotic substances is very promising, these new antibiotics should be used very carefully to avoid the development of new antibiotic resistance.

\section{СПИСОК ЛІТЕРАТУРИ References}

1. Wagenlehner F.M.E., Bjerklund J.T.E., Cai T., Koves B., Kranz J., Pilatz A., et al. Epidemiology, definition and treatment of complicated urinary tract infections. Nat Rev Urol. 2020. Vol. 17, No. 10. P. 586-600.

2. Wagenlehner F.M., Umeh O., Steenbergen J., Yuan G., Darouiche R.O. Ceftolozane-tazobactam compared with levofloxacin in the treatment of complicated urinary-tract infections, including pyelonephritis: a randomised, double-blind, phase 3 trial (ASPECT-cUTI). Lancet. 2015. Vol. 385, No. 9981. P. 1949-1956.

3. Wagenlehner F.M., Sobel J.D., Newell P., Armstrong J., Huang X., Stone G.G. et al. Ceftazidime-avibactam Versus Doripenem for the Treatment of Complicated Urinary Tract Infections, Including Acute Pyelonephritis: RECAPTURE, a Phase 3 Randomized Trial Program. Clin Infect Dis. 2016. Vol. 63, No. 6. P. 754-762.

4. Malaisri C., Phuphuakrat A., Wibulpolprasert A., Santanirand P., Kiertiburanakul S. A randomized controlled trial of sitafloxacin vs. ertapenem as a switch therapy after treatment for acute pyelonephritis caused by extended-spectrum betalactamase-producing Escherichia coli: A pilot study. J Infect Chemother. 2017. Vol. 23, No. 8. P. 556-562.

5. Seo Y.B., Lee J., Kim Y.K., Lee S.S., Lee J.A., Kim H.Y. et al. Randomized controlled trial of piperacillin-tazobactam,cefepime and ertapenem for the treatment of urinary tract infection caused by extended-spectrum beta-lactamase-producing Escherichia coli. BMC Infect Dis. 2017. Vol. 17, No. 1. P. 404.

6. Sims M., Mariyanovski V., McLeroth P., Akers W., Lee Y.C., Brown M.L. et al. Prospective, randomized, double-blind, Phase 2 dose-ranging study comparing efficacy and safety of imipenem/cilastatin plus relebactam with imipenem/cilastatin alone in patients with complicated urinary tract infections. J Antimicrob Chemother. 2017. Vol. 72, No. 9. P. 26162626.

7. Kaye K.S., Bhowmick T., Metallidis S., Bleasdale S.C., Sagan O.S., Stus V. et al. Effect of Meropenem-Vaborbactam vs PiperacillinTazobactam on Clinical Cure or Improvement and Microbial Eradication in Complicated Urinary Tract Infection: The TANGO I Randomized Clinical Trial. JAMA. 2018. Vol. 319, No. 8. P. 788-799.

8. Portsmouth S., van Veenhuyzen D., Echols R., Machida M., Ferreira J.C.A., Ariyasu M. et al. Cefiderocol versus imipenem-cilastatin for the treatment of complicated urinary tract infections caused by Gram-negative uropathogens: a phase 2, randomised, double-blind, non-inferiority trial. Lancet Infect Dis. 2018. Vol. 18. No. 12. P. 1319-1328.

9. Wagenlehner F.M.E., Naber K.G. Cefiderocol for treatment of complicated urinary tract infections. Lancet Infect Dis. 2019. Vol. 19, No. 1. P. 22-23.

10. Pharmaceuticals T. Tetraphase Announces Top-Line Results from IGNITE3 Phase 3 Clinical Trial of Eravacycline in Complicated Urinary Tract Infections (cUTI). 2018. URL: https:// www.tphase.com.

11. Kaye K.S., Rice L.B., Dane A., Stus V., Sagan O., Fedosiuk E. et al. Fosfomycin for injection (ZTI-01) vs Piperacillin-Tazobactam (PIP-TAZ) for the Treatment of Complicated Urinary Tract Infection (cUTI) Including Acute Pyelonephritis (AP): ZEUS, A Phase 2/3 Randomized Trial. Clin Infect Dis. 2019.

12. Wagenlehner F.M.E., Cloutier D.J., Komirenko A.S., Cebrik D.S., Krause K.M., Keepers T.R. et al. Once-Daily Plazomicin for Complicated Urinary Tract Infections. $N$ Engl J Med. 2019. Vol. 380, No. 8. P. 729-740. 


\section{REFERENCES \\ Список літератури}

1. Wagenlehner, F.M.E., Bjerklund, J.T.E., Cai, T., Koves, B., Kranz, J., Pilatz, A., et al. (2020). Epidemiology, definition and treatment of complicated urinary tract infections. Nat Rev Urol., 17, 10, 586-600.

2. Wagenlehner, F.M., Umeh, O., Steenbergen, J., Yuan, G., \& Darouiche, R.O. (2015). Ceftolozanetazobactam compared with levofloxacin in the treatment of complicated urinary-tract infections, including pyelonephritis: a randomised, double-blind, phase 3 trial (ASPECT-cUTI). Lancet., 385, 9981, 1949-1956.

3. Wagenlehner, F.M., Sobel, J.D., Newell, P., Armstrong, J., Huang, X., Stone, G.G., et al. (2016). Ceftazidime-avibactam Versus Doripenem for the Treatment of Complicated Urinary Tract Infections, Including Acute Pyelonephritis: RECAPTURE, a Phase 3 Randomized Trial Program. Clin Infect Dis., 63, 6, 754-762.

4. Malaisri, C., Phuphuakrat, A., Wibulpolprasert, A., Santanirand, P., \& Kiertiburanakul, S. (2017). A randomized controlled trial of sitafloxacin vs. ertapenem as a switch therapy after treatment for acute pyelonephritis caused by extendedspectrum beta-lactamase-producing Escherichia coli: A pilot study. J Infect Chemother., 23, 8, 556-562.

5. Seo, Y.B., Lee, J., Kim, Y.K., Lee, S.S., Lee, J.A., Kim, H.Y., et al. (2017). Randomized controlled trial of piperacillin-tazobactam,cefepime and ertapenem for the treatment of urinary tract infection caused by extended-spectrum beta-lactamase-producing Escherichia coli. BMC Infect Dis., 17, 1, 404.

6. Sims, M., Mariyanovski, V., McLeroth, P., Akers, W., Lee, Y.C., Brown, M.L., et al. (2017). Prospective, randomized, double-blind, Phase 2 dose-ranging study

\section{PEФEPAT}

\section{Нові антибіотики в лікуванні інфекцій сечовивідних шляхів}

\section{Ф.М. Вагенленер}

Антибіотики дуже часто призначають при симптомах інфекцій сечовивідних шляхів (ІСШ). Отже, ІСШ є важливою областю розвитку стійкості до антибіотиків. Деяків нові антибіотики були протестовані для індикації ускладненого ЇСШ / пієлонефриту. Це цефалоспорини і карбопенеми в поєднанні з новими інгібіторами бета-лактамаз, цефідерокол як новий тип цефалоспорину, плазоміцін новий аміноглікозид, еравациклін новий тетрациклін і внутрішньо- comparing efficacy and safety of imi penem/cilastatin plus relebactam with imipenem/cilastatin alone in patients with complicated urinary tract infections. J Antimicrob Chemother., 72, 9, 2616-2626.

7. Kaye, K.S., Bhowmick, T., Metallidis, S., Bleasdale, S.C., Sagan, O.S., Stus, V., et al. (2018). Effect of Meropenem-Vaborbactam vs PiperacillinTazobactam on Clinical Cure or Improvement and Microbial Eradication in Complicated Urinary Tract Infection: The TANGO I Randomized Clinical Trial. JAMA, 319, 8, 788-799.

8. Portsmouth, S., van Veenhuyzen, D., Echols, R., Machida, M., Ferreira, J.C.A., Ariyasu, M., et al. (2018). Cefiderocol versus imipenem-cilastatin for the treatment of complicated urinary tract infections caused by Gram-negative uropathogens: a phase 2, randomised, double-blind, non-inferiority trial. Lancet Infect Dis., 18, 12, 1319-1328.

9. Wagenlehner, F.M.E., \& Naber, K.G. (2019). Cefiderocol for treatment of complicated urinary tract infections. Lancet Infect Dis., 19, 1, 22-23.

10. Pharmaceuticals, T. (2018). Tetraphase Announces Top-Line Results from IGNITE3 Phase 3 Clinical Trial of Eravacycline in Complicated Urinary Tract Infections (cUTI). www.tphase.com. Retrieved from https://www.tphase.com.

11. Kaye, K.S., Rice, L.B., Dane, A., Stus, V., Sagan, O., Fedosiuk, E., et al. (2019). Fosfomycin for injection (ZTI-01) vs Piperacillin-Tazobactam (PIP-TAZ) for the Treatment of Complicated Urinary Tract Infection (cUTI) Including Acute Pyelonephritis (AP): ZEUS, A Phase 2/3 Randomized Trial. Clin Infect Dis.

12. Wagenlehner, F.M.E., Cloutier, D.J., Komirenko, A.S., Cebrik, D.S., Krause, K.M., Keepers, T.R., et al. (2019). Once-Daily Plazomicin for Complicated Urinary Tract Infections. $N$ Engl J Med., 380, 8, 729-740.

\section{РЕФЕРАТ}

\section{Новые антибиотики в лечении инфекций мочевыводящих путей}

\section{Ф.М. Вагенленер}

Антибиотики очень часто назначают при симптомах инфекций мочевыводящих путей (ИМП). Следовательно, ИМП являются важной областью развития устойчивости к антибиотикам. Некоторые новые антибиотики были протестированы для индикации осложненного ИМП / пиелонефрита. Это цефалоспорины и карбопенемы в сочетании с новыми ингибиторами беталактамаз, цефидерокол как новый тип цефалоспорина, плазомицин новый аминогликозид, 
венний фосфоміцин. Не всі антибіотики схвалені в Європі. Хоча розробка цих нових речовин $є$ багатообіцяючою, ці нові антибіотики слід використовувати дуже обережно, щоб уникнути розвитку нової стійкості до антибіотиків проти цих нових речовин.

Ключові слова: інфекції сечовивідних шляхів, Європа, резистентність, антибіотики. эравациклин новый тетрациклин и внутривенный фосфомицин. Не все антибиотики одобрены в Европе. Хотя разработка этих новых веществ является многообещающей, эти новые антибиотики следует использовать очень осторожно, чтобы избежать развития новой устойчивости к антибиотикам против этих новых веществ.

Ключевые слова: инфекции мочевыводящих путей, Европа, резистентность, антибиотики. 